\title{
The density of the bivalve Spondylus limbatus in Agua Verde-Tembabiche Gulf of California, Mexico
}

\author{
Marcial Villalejo-Fuerte ${ }^{1}$, José Borges Souza ${ }^{1}$, Marcial Arellano-Martínez ${ }^{1}$ \\ Arturo Tripp-Quezada ${ }^{1}$, Enmaylin Fernández Aguirre ${ }^{1}$, Vicente Berovides-Álvarez ${ }^{2}$ \\ Nurenskaya Velez-Arellano ${ }^{1} \&$ Amhed R. Cabrera Jerez $^{2}$ \\ ${ }^{1}$ Instituto Politécnico Nacional, Centro Interdisciplinario de Ciencias Marinas, La Paz \\ Baja California Sur, México \\ ${ }^{2}$ Facultad de Biología, Laboratorio de Genética, Universidad de La Habana, La Habana, Cuba \\ Corresponding author: Marcial Villalejo-Fuerte (mvillale@ipn.mx)
}

\begin{abstract}
This study estimated the population density of Spondylus limbatus at six fishing banks that are representative of the Gulf of California, Mexico. Each bank was identified in July 2011. There were significant differences in density between banks, and a steady north-to-south decrease in density that was fitted to a potential model. At low densities, $S$. limbatus showed a lower variability in size. Since the densities of $S$. limbatus are suitable for commercial exploitation, sustainable extraction can be performed under a population recovery approach. Also, this study represents a baseline for the evaluation and monitoring of populations of this species through time and contributes to set general guidelines for the assessment of commercial feasibility and exploitation criteria.
\end{abstract}

Keywords: Spondylus limbatus; bivalve mollusks; abundance; fishery; Gulf of California

In the Gulf of California, populations of Spondylus limbatus G.B. Sowerby II, 1847 are distributed from the intertidal zone to $18 \mathrm{~m}$ depth on rocky bottoms with gravel or sand (Skoglund \& Mulliner, 1996). This species has been exploited for hundreds of years throughout the east-central Pacific, including the Mexican coasts (SEMARNAT, 2005). The adductor muscle ("callo") is marketed as a food product, and the shell is used in the elaboration of handcrafts (Skoglund \& Mulliner, 1996; Villalejo-Fuerte \& MuñetónGómez, 2002). Authorized commercial fishing of this species is carried out in the upper part of the Gulf of California, but no structured fishery has evolved in the central-western area. In the Agua Verde-Tembabiche fishing area, the commercial exploitation of local populations or banks of $S$. limbatus started in 2010, through fishing permits granted sporadically when the abundance of other species of higher fishery value drops. However, no official fisheries statistics of these catches are currently available (Villalejo-Fuerte $e t$ al., 2015). This species is listed as subjected to special protection in the Mexican Official Standard NOM-059-
SEMARNAT 2001. Thus, its exploitation and management should be carried out following the General Law of Ecological Equilibrium and Environmental Protection and the General Wildlife Act (DOF, 2010). Therefore, it is recommended that fishing activities be carried out under appropriate regional management regulations, which should be strictly implemented (SEMARNAT, 2005). In the Loreto and Agua Verde zone, anecdotal evidence from fishers describes that this resource was highly abundant in the past. However, the only published work on the abundance of this species on the coasts of Baja California Sur reports low densities and states that shallow banks have been either overexploited or depleted; additionally, the species is considered as endangered (Baqueiro-Cárdenas et al., 1982). Since knowledge about the abundance of a species is essential to assess the status of populations, the first objective of this work as to estimate the density of S. limbatus in six of the main fishing areas within the Agua VerdeTembabiche fishing zone located in the central-western region of the Gulf of California (Fig. 1).

Corresponding editor: Eduardo Ríos 


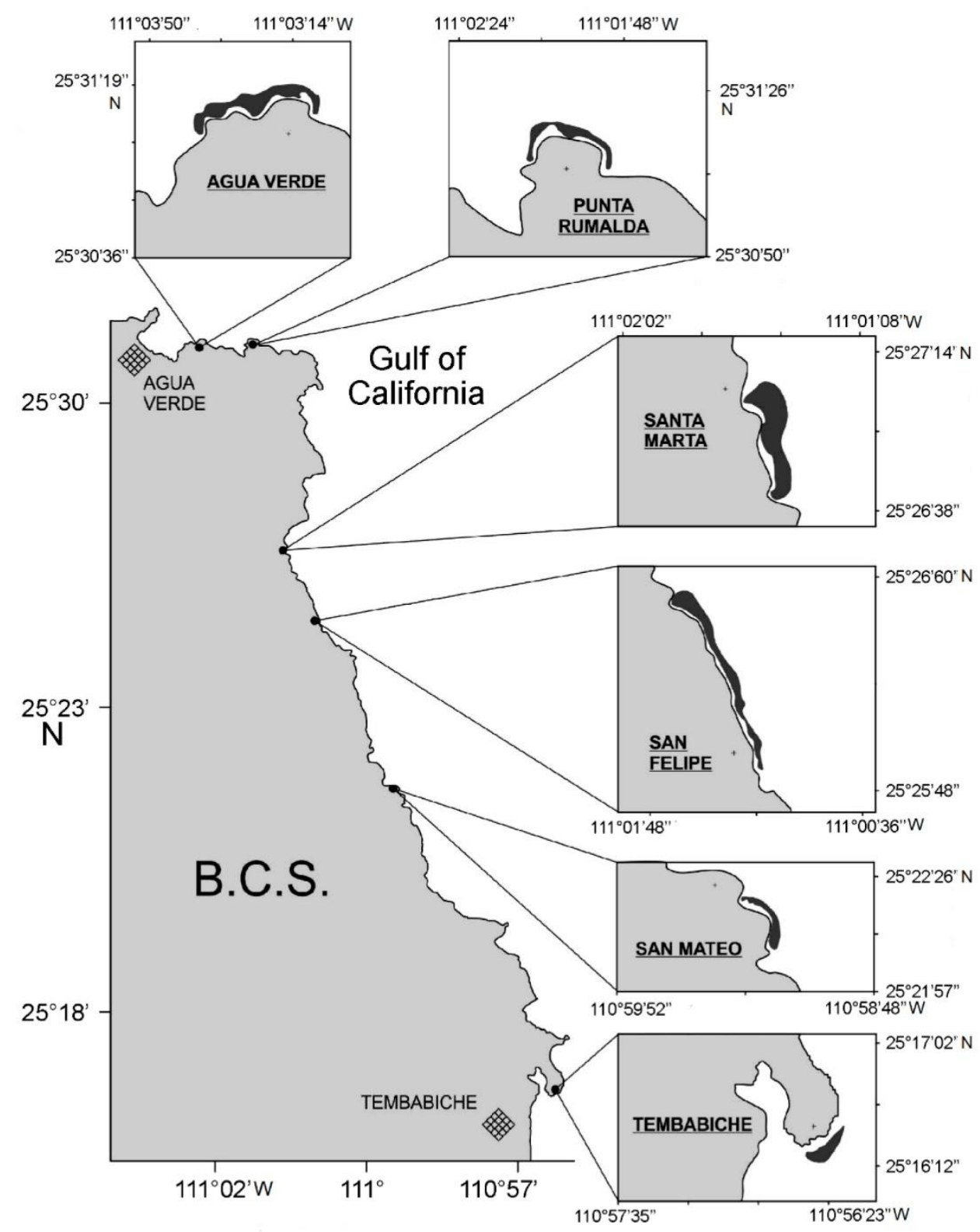

Figure 1. Most important banks of Spondylus limbatus in the Agua Verde-Tembabiche fishing area. Areas in black indicate the estimated shape and length of each bank.

In addition, we evaluated the effects of depth, site and substrate size on the density of fishing banks. This information is essential to provide scientifically sound proposals to establish conservation strategies. To this end, six banks representative of the fishing areas of $S$. Limbatus were selected, according to local fishers, and classified by the size of the substrate (Table 1, Fig. 1).

In July 2011, each bank was surveyed by boat, marking and geo-referencing the border of each bank with a GPS (GPSMAP76CSx ${ }^{\circledR}$ ). The depth and bottom structure of each bank were determined using a Garmin ${ }^{\circledR}$ Echo 551d 77/200 kHz HD-ID echo sounder / Down $\mathrm{Vu}$ transducer. According to the profile of the seabed, banks were sorted into two groups: rocky substrate, when it was composed of smooth low rocks $(<50 \mathrm{~cm})$, and very rocky substrate, when it included substrates with high rocks $(>50 \mathrm{~cm})$. The population density was estimated through semi-autonomous diving (hookah), with transects running parallel to the coast at two depths $(5$ and $10 \mathrm{~m})$; each transect consisted of a $50 \mathrm{~m}$ line (SEMARNAT, 2010).

Quadrats $\left(5 \mathrm{~m}^{2}\right)$ were placed at $5 \mathrm{~m}$ intervals along each transect from position 0 to $50 \mathrm{~m}$. All individuals recorded in each quadrat were counted. Oysters were sorted into three size categories: small $(<90 \mathrm{~mm}$ shell height, $\mathrm{SH}$ ), medium (between 90 and $130 \mathrm{~mm} \mathrm{SH}$ ), and 
Table 1. Area and type of substrate of the most important Spondylus limbatus banks in the Agua Verde-Tembabiche fishing area, Gulf of California.

\begin{tabular}{lcl}
\hline Banks & $\begin{array}{r}\text { Estimated } \\
\text { area }\left(\mathrm{m}^{2}\right)\end{array}$ & Substrate size \\
\hline Agua Verde & 92,689 & Very Rocky $(>50 \mathrm{~cm})$ \\
Punta Rumalda & 36,817 & Very Rocky $(>50 \mathrm{~cm})$ \\
Santa Marta & 23,941 & Very Rocky $(>50 \mathrm{~cm})$ \\
San Felipe & 5,644 & Rocky $(<50 \mathrm{~cm})$ \\
San Mateo & 23,941 & Rocky $(<50 \mathrm{~cm})$ \\
Punta Tembabiche & 68,570 & Rocky $(<50 \mathrm{~cm})$ \\
\hline
\end{tabular}

large $(>130 \mathrm{~mm} \mathrm{SH})$. The population density was estimated based on the number of individuals per square meter. Differences in density were statistically significant (Kruskal-Wallis, $P<0.05$ ) between banks. A post-hoc Dunn's test revealed that bank density is higher in Agua Verde. When density gradients between banks were explored, a north-to-south decrease in density was observed (Fig. 2).

The most favorable conditions for Spondylus limbatus occur to the north of the study area where rocky substrates are more abundant, promoting the development of this species. The Agua Verde, Punta Rumalda and Santa Marta banks showed higher densities and recorded a higher proportion of rocky substrates; this was observed during sampling, as the type of substrate in each bank was recorded. The best fit to describe the variation in population density across study sites was a potential negative relationship (Fig. 2).

The minimum (1.37 ind $\mathrm{m}^{-2}$ ), maximum (3.88 ind $\left.\mathrm{m}^{-2}\right)$, and mean $\left(2.51\right.$ ind $\left.\mathrm{m}^{-2}\right)$ densities estimated in this study differ from those in the Mediterranean Sea for Spondylus spinosus (3.4 and 4.4 ind $\mathrm{m}^{-2}$ ) (Shabtay et al., 2014) and S. gaedoropus (2.3 and 6.8 ind $\mathrm{m}^{-2}$ ) (Kersting et al., 2006). Similar values are reported for other genera of bivalves that live attached to hard substrates, such as Pinctada mazatlanica in California, where the mean density was 1.2 ind $\mathrm{m}^{-2}$ (Solano-Lopez et al., 1997), while P. mazatlanica in Costa Rica reached a density of 2.4 ind $\mathrm{m}^{-2}$ (Cipriani et al., 2008). These densities have been recorded for medium-sized bivalves, while larger species of the genus Tridacna that also live attached to the substrate show lower densities (Militz et al., 2015). On the other hand, species that live buried in sandy substrates show higher densities, as is the case of Panopea generosa, with a density of 3.0 ind $\mathrm{m}^{-2}$ on the USA Pacific coast (McDonald et al., 2015).

No significant differences were observed between depth and density (Mann-Whitney $\mathrm{U}$ test; $P<0.05, \mathrm{Z}=$ 0.40 ) in any of the sites studied. The overall analysis of

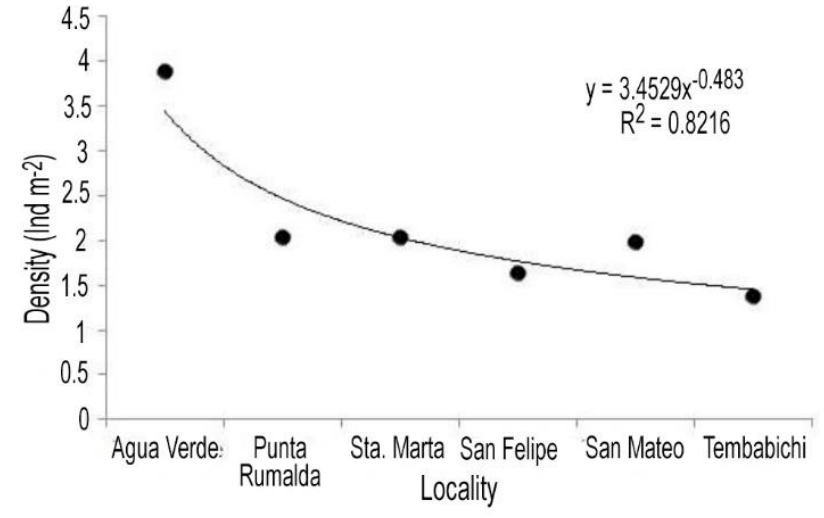

Figure 2. Relationship between density (ind $\mathrm{m}^{-2}$ ) and locality for Spondylus limbatus in six banks across the Agua Verde-Tembabiche fishing area, Gulf of California, Mexico.

Table 2. Density (ind $\mathrm{m}^{-2}$ ) of Spondylus limbatus by size class in the six banks evaluated in the Agua VerdeTembabiche fishing area, Gulf of California, Mexico. The number of samples (n), mean density (X), standard deviation (SD), and coefficient of variation (CV).

\begin{tabular}{lcccc}
\hline Individual size & $\mathrm{n}$ & $\mathrm{X}$ & $\mathrm{SD}$ & $\mathrm{CV}$ \\
\hline Small & 119 & 2.62 & 2.32 & 88.54 \\
Medium & 108 & 2.55 & 2.11 & 82.74 \\
Large & 88 & 2.23 & 1.59 & 71.30 \\
Kruskal-Wallis test & \multicolumn{4}{l}{$\mathrm{X}^{2}=0.9, P<0.05$} \\
\hline
\end{tabular}

density by size class showed no significant differences (Kruskal-Wallis test, $\alpha=0.05$ ). However, a trend in the association between lower densities and larger shell sizes was observed (Table 2).

The results of the analysis of the density-depth-shell size relationship showed a steady decrease in density related to shell size at $5 \mathrm{~m}$ depth, with the smallest individuals showing the highest density $\left(2.95 \mathrm{ind} \mathrm{m}^{-2}\right)$, while larger organisms were less abundant $\left(1.9 \mathrm{ind} \mathrm{m}^{-2}\right)$, and medium-sized individuals showed intermediate values $\left(2.36\right.$ ind $\left.\mathrm{m}^{-2}\right)$. In contrast, at $10 \mathrm{~m}$ depth, there is a higher density of medium-sized individuals (2.85 ind $\mathrm{m}^{-2}$ ) and a lower density of small organisms (2.26 ind $\mathrm{m}^{-2}$ ), while large individuals showed an intermediate density $\left(2.53\right.$ ind $\left.\mathrm{m}^{-2}\right)$.

For most banks studied, the bank $\times$ shell size interaction showed a density of about 2.0 ind $\mathrm{m}^{-2}$. Exceptions are Agua Verde and Punta Rumalda, where large and small individuals predominate, respectively (Table 3).

The predominance of larger individuals can be attributed to the sampling method used in this study, which does not facilitate the detection of small individuals. 
Table 3. Interaction between density (ind $\mathrm{m}^{-2}$ ), individual size and depth in banks of Spondylus limbatus in the Agua VerdeTembabiche fishing area, Gulf of California, Mexico.

\begin{tabular}{lcccccc}
\hline \multirow{3}{*}{ Bank } & \multicolumn{3}{c}{ Individual size } & & \multicolumn{2}{c}{ Depth } \\
\cline { 2 - 3 } \cline { 6 - 7 } & $\begin{array}{c}\text { Small } \\
\left(\text { ind }^{-2}\right)\end{array}$ & $\begin{array}{c}\text { Medium } \\
\left(\text { ind m }^{-2}\right)\end{array}$ & $\begin{array}{c}\text { Large } \\
\left(\text { ind m }^{-2}\right)\end{array}$ & & $\begin{array}{c}5 \mathrm{~m} \\
\left(\text { ind m }^{-2}\right)\end{array}$ & $\begin{array}{c}10 \mathrm{~m} \\
\left(\text { ind m }^{-2}\right)\end{array}$ \\
\hline Agua Verde & 2.82 & 4.80 & 3.81 & & 3.08 & 4.58 \\
Punta Rumalda & 3.44 & 1.14 & 1.12 & & 2.09 & 2.45 \\
Santa Marta & 1.78 & 1.89 & 2.66 & & 1.33 & 2.62 \\
San Felipe & 1.69 & 1.58 & 1.61 & & 1.76 & 1.56 \\
San Mateo & 1.84 & 2.33 & 1.71 & & 2.17 & 1.73 \\
Punta Tembabiche & 1.43 & 1.50 & 1.11 & & 1.17 & 1.55 \\
\hline
\end{tabular}

Table 4. Combined effect of the bank $\times$ depth $\times$ shell size interaction on Spondylus limbatus density (ind $\mathrm{m}^{-2}$ ) in the Agua Verde-Tembabiche fishing area, Gulf of California, Mexico.

\begin{tabular}{lcccc}
\hline \multirow{2}{*}{ Bank } & \multirow{2}{*}{ Depth $(\mathrm{m})$} & \multicolumn{3}{c}{ Shell size } \\
\cline { 3 - 5 } & & Small & Medium & Large \\
\hline Agua Verde & 5 & 1.62 & 2.10 & 1.50 \\
& 10 & 1.79 & 2.44 & 2.18 \\
Punta Rumalda & 5 & 1.22 & 1.28 & 1.23 \\
& 10 & 1.57 & 1.34 & 1.15 \\
Santa Marta & 5 & 1.62 & 1.91 & 1.41 \\
& 10 & 1.52 & 1.40 & 1.40 \\
San Felipe & 5 & 1.31 & 1.27 & 1.18 \\
& 10 & 1.42 & 1.38 & 1.52 \\
San Mateo & 5 & 1.41 & 1.50 & 1.22 \\
& 10 & 1.66 & 1.66 & 1.95 \\
Punta Tembabiche & 5 & 1.54 & 1.14 & 1.04 \\
& 10 & 1.93 & 1,15 & 1.29 \\
\hline
\end{tabular}

Regarding the relationship of bank density-depth (Table 3), the density of the banks is higher at $10 \mathrm{~m} v s$. $5 \mathrm{~m}$ in Agua Verde, Punta Rumalda and Santa Marta. However, an inverse relationship between density and depth is observed in San Felipe and San Mateo (higher density at $5 \mathrm{~m}$ ), while density is higher at $10 \mathrm{~m}$ in Punta Temba. In the province of Esmeralda, Ecuador, Aguilar et al. (2013) reported a maximum density of 0.026 ind $\mathrm{m}^{-2}$ for Spondylus limbatus $(=$ S. calcifer $)$ and of 0.008 ind $\mathrm{m}^{-2}$ for $S$. princeps at $12 \mathrm{~m}$ depth, in areas with substrates of irregular medium-sized stones covered with fine sediment and small embedded algae; these densities are lower than those found in the present study, and the positive relationship between density and depth coincides in both studies. This cross-interaction regarding depth could be because the densityregulating factor is not the size of rocks of the substrate since it was similar. Instead, it is somewhat related to other factors not recorded in this study. Separately, no statistically significant differences (Mann-Whitney U test, $\mathrm{Z}=0.40, P>0.05$ ) are evident in the effects of either depth or shell size on the density. However, when we analyze the triple bank $\times$ depth $\times$ shell size interaction, noticeable changes in density were detected within each bank with respect to the shell size (Table 4).

Agua Verde and Punta Rumalda are the sites where the bank $\times$ shell size interaction is most evident; these show a pattern of a higher density of medium-sized organisms in the first bank and smaller organisms in the second, regardless of depth.

The particular conditions of each bank should be taken into account to analyze these patterns; the concentration of nutrients, waves, characteristics of the habitat and degree of exploitation by commercial fishing might be affecting the local populations of $S$. limbatus.

Depth affected the abundance of large and small individuals in Agua Verde, but only of the large organisms in Punta Rumalda. The banks at Punta Temba and San Mateo shared similar characteristics, i.e., prevalence of medium-sized individuals at $5 \mathrm{~m}$ depth and of small organisms at $10 \mathrm{~m}$, which explains the minor influence of shell size and depth on bank 
density. Finally, in the case of San Felipe, a higher density of small individuals was observed at $5 \mathrm{~m}$, and of large organisms at $10 \mathrm{~m}$, while Santa Marta showed a higher density of medium-sized individuals at $5 \mathrm{~m}$, and of large individuals at $10 \mathrm{~m}$; this explains the crossinteraction mentioned above.

In sites where this species is found at greater depth, densities range from 1 to 5 individuals per $25 \mathrm{~m}^{2}$, the latter being a suitable density for commercial exploitation. Baqueiro et al. (1982) reported a decrease in the abundance of S. limbatus in Baja California Sur but made no comparisons of density between fishing sites, which highlights the importance of the results obtained in the present work. Based on our results, we concluded that the densities of $S$. limbatus in the Agua Verde-Tembabiche fishing area of the Gulf of California, Mexico, are suitable for commercial exploitation; this study sets a baseline for the assessment and monitoring of these populations.

\section{ACKNOWLEDGMENTS}

The authors wish to thank Alejandra Chávez Hidalgo and Francisco Domínguez Contreras, for their collaboration in the dives; to Norberto Capetillo Piñar and Gaspar Romero, for their support to locate banks. Thanks also to Armando Hernandez for his assistance in georeferencing, the calculation of areas, and the elaboration of maps. María Elena Sánchez-Salazar translated the manuscript into English. This research was funded by the SIP projects 20110521 and SEMARNAT-CONACyT 108230.

\section{REFERENCES}

Aguilar, F., Mendívez, W. \& Revelo, W. 2013. Distribución y abundancia de la concha Spondylus (Spondylus calcifer y S. princeps) en las provincias de Esmeraldas, Manabí, Santa Elena y El Oro. Boletín Científico y Técnico, 23(1): 73-98.

Baqueiro-Cárdenas, E.J., Masso, A. \& Guajardo, H. 1982. Distribución y abundancia de moluscos de importancia comercial en Baja California Sur. Instituto Nacional de la Pesca, Serie de Divulgación, 11: 32 pp.

Cipriani, R., Guzman, H.M. \& Lopez, M. 2008. Harvest history and current density of the pearl oyster Pinctada mazatlanica (Bivalvia: Pteriidae) in Las Perlas and Coiba Archipelago, Panama. Journal of Shellfish Research, 27(4): 691-700.

Received: 13 July 2018; Accepted: 2 October 2019
Diario Oficial de la Federación (DOF). 2010. Ley general del equilibrio ecológico y la protección al ambiente. Última Reforma, DOF 04-06-2012.

Kersting, D.K., García-March, J.R. \& Templado, J. 2006. Evaluation of Spondylus gaederopus Linné, 1758, mass mortality event in the Columbretes Islands Marine Reserve (western Mediterranean, Spain). International Congress on Bivalvia, Barcelona. [http://senckenberg.de/odes/06-16.htm]. Reviewed: April 14, 2018.

McDonald, P.S., Essington, T.E., Davis, J.P., Galloway, E., Stevick, B.C., Jensen, G.C., Vanblaricom, G.R. \& Armstrong, D.A. 2015. Distribution, abundance, and habitat associations of a large bivalve (Panopea generosa) in a eutrophic fjord estuary. Journal of Shellfish Research, 34(1): 137-145.

Militz, T., Kinch, A.J. \& Sauthgate, P.C. 2015. Population demographics of Tridacna noae (Röding, 1798) in New Ireland, Papua New Guinea. Journal of Shellfish Research, 34(2): 329-335.

Secretaría de Medio Ambiente y Recursos Naturales (SEMARNAT). 2005. Plan de Manejo Regional del Callo de Escarlopa (Spondylus calcifer) en el Golfo de California. Dirección General de Vida Silvestre, SEMARNAT, $26 \mathrm{pp}$.

Secretaría de Medio Ambiente y Recursos Naturales (SEMARNAT). 2010. Protección Ambiental-Especies nativas de México de flora y fauna silvestres-Categorías de riesgo y especificaciones para su inclusión, exclusión o cambio-Lista de especies en riesgo. NOM-059SEMARNAT-2010, 35 pp.

Shabtay, A., Tikochinsky, Y., Benayahu, Y. \& Rilov, G. 2014. Preliminary data on the genetic structure of a highly successful invading population of oyster. Marine Biology Research, 10: 407-415.

Skoglund, C. \& Mulliner, K. 1996. The genus Spondylus (Bivalvia: Spondylidae) of the Panamic Province. Festivus, 28(9): 93-107.

Solano-López, Y., Cabrera-Peña, J., Palacios, J.A. \& Cruz, R.A. 1997. Madurez sexual, índice de condición y rendimiento de Pinctada mazatlanica (Pterioida: Pteriidae), Golfo de Nicoya, Costa Rica. Revista de Biología Tropical, 45(3): 1049-1054.

Villalejo-Fuerte, M. \& Muñetón-Gómez, M.S. 2002. Tópicos sobre la biología de la almeja burra Spondylus calcifer (Carpenter, 1857). Hidrobiológica, 12(1): 7987.

Villalejo-Fuerte, M., Arellano-Martínez, M., CeballosVázquez, P., González-Castro, D., Berovides-Álvarez, V., Tripp-Quezada, A. \& Tripp-Valdez, A. 2015. Spondylus calcifer Carpenter, 1857: antecedentes de la especie. Amici Molluscarum, 23(1-2): 39-42. 